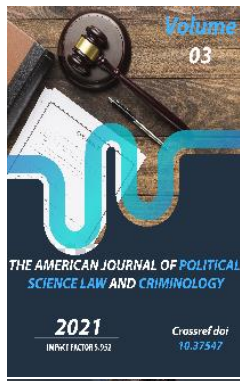

Journal Website: http://usajournalshub.c om/index,php/tajpslc

Copyright: Original content from this work may be used under the terms of the creative commons attributes 4.0 licence.

\section{An Introduction Of The Election System Of Local Government Leaders: Creating Organizational And Legal Framework Is A Priority}

\author{
Shakhobiddin Abduadizovich Kholboev \\ Master Student, Academy Of Public Administration Under The President Of The Republic Of \\ Uzbekistan
}

\title{
ABSTRACT
}

This article describes the use of majoritarian, proportional and mixed types of electoral systems in the practice of state building in the world, and discusses issues related to the use of these types as electoral systems in some countries around the world. The article also provides an in-depth study of the application of these systems in our country.

\section{KEYWORDS}

Election, electoral system, majoritarian, proportional and mixed types, electoral code, local executive power.

\section{INTRODUCTION}

It is well known that elections play an important role in building a democratic state governed by the rule of law and civil society. Therefore, from the first days of independence of our country, special attention is paid to the formation of electoral legislation based on democratic principles.

First of all, the Constitution of the Republic of Uzbekistan enshrines the right of citizens to 
participate in the management of public and state affairs directly and through their representatives. Their right to vote and to be elected to representative bodies of state power, the right to vote, equality and freedom of expression of their will are constitutionally guaranteed in a separate chapter. Five laws regulating the organization and conduct of elections to public authorities have been adopted.

In general, the electoral system is a set of electoral procedures and the legal norms that establish them. The electoral system includes all the voting rights of citizens, the existing procedure for the formation of state representative bodies and the procedure for involving citizens in elections, the organization of elections and the interaction of deputies with voters. Majority, proportional and mixed forms of electoral system are used in the practice of state building in the world. These species have been studied many times by domestic and international researchers. However, in this article we would like to briefly dwell on these types of elections that are used in many countries as a system today.

\section{THE MAIN FINDINGS AND RESULTS}

In the system of majoritarian elections (French. majorite - from the word majority) means the determination of the results of voting in the representative bodies. The candidate (or list of candidates) who receives the majority of votes established by law is considered elected in a certain constituency. In modern constitutional law, majoritarian electoral systems based on a relative, absolute and qualified majority vote are used. For example, USA, UK, India, Mexico et al. In a majoritarian system based on an absolute majority vote, a candidate who receives an absolute (or simple) majority vote (i.e., $50 \%+1$ vote) of the total number of votes cast and deemed valid shall be deemed elected. If none of the candidates receives enough votes, a re-vote will be held, leaving 2 candidates with the most votes on the list of candidates. Sometimes, instead of repeat voting, a second round of voting is held, the results of which are determined by a different system (for example, in France, the National Assembly is a majoritarian system based on an absolute majority in parliamentary elections, and in a second round of voting is a relative majority). The majority system, based on a relative majority vote, is the simplest system, in which the candidate is considered to have received the most votes from each of his or her opponents. In this system, a party that does not often have the support of the electorate can have multiple seats in parliament. This form of majority system is used in the United States, the United Kingdom, and many other countries. There is also a majoritarian system based on a rare majority, which is rarely used $(2 / 3,3 / 4$ of the total votes) (for example, in Chile, such a system is used in elections to the lower house of parliament - the Chamber of Deputies). However, since only very few candidates can get $65 \%$ of the vote, mandates are usually distributed according to a proportional representation system. Depending on the number of deputies elected from each constituency, there may be singlemember or multi-member majoritarian electoral systems. In a single-member majority system, a deputy is elected from one constituency. In a multi-member majority system, several deputies are elected from one constituency.

The proportional electoral system is a more complex procedure for determining the results of voting, in which the mandates are 
distributed among the political parties that nominated their candidates to the representative bodies and other mass movements according to the number of votes they received. In a proportional electoral system, large constituencies are formed in which each party nominates a list of its representatives, and voters vote for a list of representatives nominated by the respective parties or mass movements. To determine the results of voting, an election criterion (yokikvota), the number of votes required to win a seat (usually at least $4-5 \%$ ) is set. In this case, according to the condition, the candidates of certain public associations participate in the distribution of mandates only after receiving the specified votes. First of all, the number of votes cast is divided by the number of seats. Then the number of votes in the single mandate will be known. The votes received by each party are then counted separately. It is divided by the number of votes required for one mandate of the deputy. Then comes the number of seats allocated to this political party or mass movement. In such a system, the voter actually votes for a political party, not for a candidate. The number of deputies' mandates shall be determined in accordance with the established norms and proportionally. These seats are given by the party's governing bodies to candidates who are at the top of the party list. The proportional electoral system is available in Israel, Hungary, Austria, Denmark, Spain, Poland and other countries.

The mixed electoral system incorporates elements of both majoritarian and proportional electoral systems. In Germany, for example, a mixed system is used in elections to the Bundestag. Half of its deputies are elected in single-member constituencies across the country on the basis of a relative majority, while the other half are elected on a proportional system based on a list of candidates nominated by political parties in German lands (federations), which are multimember constituencies.

The mixed electoral system is also used in Bulgaria, Georgia, Lithuania, Italy and other countries.

The electoral system of the Republic of Uzbekistan is regulated by the Constitution of the country and the relevant laws on elections. According to them, Uzbekistan has a majority electoral system. For example, a candidate for deputy of the Legislative Chamber of the Oliy Majlis of the Republic of Uzbekistan and local authorities must receive more than half of the votes cast in the constituency. An election shall be deemed invalid if less than half of the voters included in the voter list participated in the election. If more than 2 candidates are elected in a constituency and none of them receives a majority of votes, i.e. is not elected as a deputy, the district election commission shall decide to re-vote the 2 candidates who received the most votes in the constituency. This decision will be sent to the Central Election Commission. Based on the decision of the Central Election Commission, repeat voting will be held in 2 weeks.

In pursuance of the tasks set in the Action Strategy for the five priority areas of development of the Republic of Uzbekistan for 2017-2021, for the first time in the history of our country in 2019, an integrated law covering all legal norms related to elections was adopted. During the development of this important document, 5 election laws and about 40 legal documents of the Central Election Commission, more than 10 international 
election documents, electoral legislation of more than 50 foreign countries were analyzed. 10 recommendations of the OSCE Office for Democratic Institutions and Human Rights and the Venice Commission have been included in the Electoral Code of the Republic of Uzbekistan. It was widely discussed and examined by international organizations and implemented.

The Code contains more than thirty new norms and rules that serve to conduct elections in a democratic, open and transparent manner on the basis of universally recognized international standards and principles, and removes many of the existing restrictions.

The Electoral Code, adopted on June 25, 2019, set reasonable requirements for signatures in support of candidates.

The Electoral Code has created a legal framework for greater opportunities for citizens and voters. Previously, citizens were able to elect candidates to the Legislative Chamber from only 135 constituencies, but now this number has increased to 15 and now stands at 150 . This, of course, will serve to further increase the capacity of citizens in the management of public affairs, expand the representation of citizens, and increase their influence on government [1, p. 26].

Germany's electoral system is governed by the country's 1949 Constitution and the 1993 Federal Election Law. At the same time, the normative legal acts of the German states also apply. The elections in the country will be held in 3 stages.

Successful implementation of large-scale reforms at the current stage of the country's development and the achievement of the goals of the Action Strategy for the five priority areas of development of the Republic of Uzbekistan in 2017 / - / 2021 requires the organization of harmonious activities of public administration bodies and local executive authorities.

At the same time, the institutional framework of some executive bodies and economic management bodies that do not meet modern requirements and the principles of their activities hinder the full implementation of reforms and the achievement of goals.

There are still a number of systemic problems and shortcomings that hinder the successful implementation of state policy on modernization of economic sectors and the social sphere, comprehensive development of the regions, improving the living standards and welfare of the population, in particular:

- $\quad$ First, the basis for organizing the activities of the executive authorities does not provide timely solutions to the problems that have accumulated on the ground, slowing down the pace of development of the regions;

- Secondly, the declarative nature of the tasks assigned to some executive bodies, the lack of organizational and legal mechanisms for their implementation, the duplication of tasks and the existence of cases of excessive government regulation have a negative impact on the effectiveness of ongoing reforms;

- Thirdly, the current system of coordination and control over the activities of the executive branch does not provide timely identification and elimination of systemic problems that hinder the implementation of decisions;

- Fourth, the mechanisms for assessing the performance of the executive branch consist only of the recording of cases and 
the current collection of statistics, which in most cases does not reflect the true state of affairs on the ground;

- Fifth, there are no clear boundaries of the responsibilities of the executive authorities and their leaders, in particular, effective mechanisms of internal departmental and interdepartmental cooperation of the executive authorities on the ground;

- Sixth, the over-centralization of state functions and powers leads to a decrease in the role of local executive authorities in the formation of regional development programs and solving the most important problems of the population;

- Seventh, the level of introduction of modern innovative methods of planning and organization of work in the management process, advanced information and communication technologies does not allow to ensure the effective implementation of decisions and rapid monitoring of its process; it also leads to excessive bureaucracy and high costs in public administration;

- Eighth, the combination of regulatory and economic functions of the state by economic management bodies; an outdated network management system that does not have sufficient flexibility and market orientation, unreasonable provision of individual privileges, preferences and advantages hinders the development of a healthy competitive environment;

- Ninth, the underdevelopment of social and public-private partnerships limits the participation of NGOs and businesses in solving pressing socio-economic problems and, consequently, does not ensure a reduction in budget expenditures;
- Tenth, insufficient openness and transparency of the executive branch, weak mechanisms of public control lead to excessive bureaucracy and various forms of corruption;

- Eleventh, the lack of responsibility and initiative of some leaders has a negative impact on the timely and quality solution of tasks and targets for integrated socioeconomic development of the regions [2].

"There is a lot of talk about electing governors. I said that myself. But there is a question: are we ready to elect governors now? We can't elect a single mahalla chairman fairly", he said. [3].

At the same time, a proposal on "Introduction of the practice of popular election of governors" was posted on the portal of public appeals "Meningfikrim" to be studied and commented on by the population of our country on this issue. In particular, it says:

"Ensuring the effectiveness of reforms in our country depends on the dedication, enthusiasm, knowledge and ability to work with the people of civil servants. In this regard, the responsibilities and obligations of district governors in particular are very high. Therefore, it is important to introduce the practice of electing city and district mayors by the people as soon as possible. It is known from social networks that there is now a public outcry against many governors. Therefore, it is necessary to introduce the practice of selfelection and election of governors in the regions. Only then will our governors hear the people's grievances and work with them. He will also make every effort to fulfill the tasks and instructions given by the President. 
A fixed number of candidates must be selected from each district or city, and the most suitable of them must be elected. It is advisable to leave the assessment of the work of the elected governor to the people. It is necessary to develop and implement a separate legislation in this regard "[4].

The petition was attended by more than 36.5 thousand people, who expressed their views on the election of these governors by the people.

At the same time, the issue has been the subject of much discussion on social media: from ordinary citizens to political scientists and MPs, who have expressed their views on the "election of governors".

It should be noted that some well-known political scientists and even representatives of the people did not take a deep approach to the issue and did not have a clear conclusion (people are ready to elect governors, those who allow it are not ready") ...

Indeed, in the electoral system of developed countries, or even in countries where today the leadership of local government is determined by elections, in order to put into practice a particular system, first of all, its goals and objectives are defined and a mechanism is developed; the legal framework is formed, the necessary normative legal acts of national legislation are adopted.

\section{CONCLUSION}

Based on the above, the following general conclusions can be drawn on the democratization of local government and administration.
- Further democratization of the principle of constitutional division of local government;

- Management structures of local executive power, new methods of electing heads of local government, implementation of work on their election in cooperation with other states;

- Limiting centralization in local government;

- Ensuring the coordinated functioning and cooperation of local authorities as governors;

- Further improve the distribution of local government, executive;

- A new stage of modernization, reform and democratization of the political system has been entered. Expanding the powers of local executive authorities on the basis of amendments and additions to the Constitution of the Republic of Uzbekistan;

- Election of governors, a number of issues related to the activities of public receptions, the development of new initiatives.

It should be noted that all the experiences of socio-economic formations that have lived throughout the life of mankind should serve to ensure future development, that is, a prosperous and happy life of man. In a globalizing world, democracy is also a non-stop process that results in the formation, interaction, and influence of different views and systems in different forms and purposes. Improving the electoral legislation on the basis of the requirements of democratization and modernization of society will inevitably serve the interests of the people, guarantee equal conditions for free and voluntary participation of citizens in the management of public affairs, directly and through their representatives. 


\section{REFERENCES}

1. Alimov R. (2002). Parliamentarism: the experience of foreign countries. Tashkent. Shark. - р. 26. (Алимов Р. Парламентаризм: хорижий мамлакатлар тажрибаси. Тошкент. Шарк, 2002. -26 бет.)

2. Decree of the President of the Republic of Uzbekistan "On approval of the concept of administrative reform in the Republic of Uzbekistan", 8.09. 2017. (“Ўзбекистон Республикасида маъмурий ислохотлар концепсиясини тасдиқлаш тўғрисида"ги Ўзбекистон Республикаси Президенти Фармони, 8.09. 2017.)

3. https://www.gazeta.uz/uz/2021/03/19/elec tions/

4. https://meningfikrim.uz/uz/petitions/view/ 3842

5. Electoral Code of the Republic of Uzbekistan, https://lex.uz/docs/4386848 (Ўзбекистон Республикасининг Сайлов Кодекси, https://lex.uz/docs/4386848) 